\title{
Comparative study on the accelerated thermal aging behavior between palm and rapeseed natural ester oils
}

\author{
N. L. M. Ridzuan, N. A. Bakar, S. A. Ghani, I. S. Chairul, N. H. A. Aziz \\ High Voltage Engineering Research Laboratory, Centre for Robotics and Industrial Automation, Faculty of Electrical \\ Engineering, University Technical Malaysia Malacca, Malaysia
}

\begin{tabular}{l} 
Article Info \\
\hline Article history: \\
Received Jan 9, 2019 \\
Revised Mar 12, 2019 \\
Accepted Mar 29, 2019 \\
\hline Keywords: \\
Acidity \\
Insulating liquid \\
Moisture content \\
Power transformer \\
Ultraviolet-visible spectroscopy
\end{tabular}

\begin{abstract}
The suitability of natural ester oils as an insulating medium in power transformers is discussed in this paper. Owing to environmental concerns, natural ester oils have great potential as mineral oil substitutes in power transformers. In this paper, the aging behaviors of palm and rapeseed natural ester oils were compared with that for mineral oil. The performance of these natural ester oils was assessed based on their properties (moisture content, acidity, and relative content of dissolved decay products) after accelerated thermal aging. The results showed that the palm oil has better performance compared to the rapeseed oil after accelerated thermal aging for $1500 \mathrm{~h}$ because of its lower acidity. This was further supported by the presence of sludge in the rapeseed oil after $1500 \mathrm{~h}$ of aging.
\end{abstract}

Copyright $@ 2019$ Institute of Advanced Engineering and Science. All rights reserved.

\section{Corresponding Author:}

Norazhar Abu Bakar,

High Voltage Engineering Research Laboratory,

Centre for Robotics and Industrial Automation,

Faculty of Electrical Engineering, University Technical Malaysia Malacca, Malaysia.

Email: norazhar@utem.edu.my

\section{INTRODUCTION}

Large oil-filled power equipment such as power transformers are essential in power systems. Hence, it is important to conduct regular monitoring and diagnosis of power transformers, which will affect the remnant life of the transformers [1-5]. Mineral insulating (MI) oils are typically used as the insulating and cooling medium in transformers [6-10]. However, there is a growing trend on the use of natural ester insulating (NEI) oils as MI oil substitutes because of their excellent biodegradability and environmental compatibility [7-9, 11-18]. By principle, the properties of insulating oils will degrade due to the combination of several factors such as electrical arcing, thermal aging, and oxidation [2, 3, 13, 19-23]. In general, transformer insulating oils have a critical temperature, which should not be exceeded to prevent electrical breakdowns. Beyond this temperature, the oil will degrade gradually and the insulating properties of the oil will eventually be lost due to thermal effects [3, 19, 24-26]. Hence, in this work, the performance of palm and rapeseed NEI oils was investigated based on laboratory thermal aging experiments at $130^{\circ} \mathrm{C}$ for $1500 \mathrm{~h}$. The acidity level, moisture content, and relative content of desolved decay products (DDP) were measured for these oils and the results are presented in this paper.

\section{METHODOLOGY}

Three transformer insulating oils were chosen for this work: MI oil, palm oil, and rapeseed oil. MI oil was used as the basis for comparison with the NEI oils. The initial moisture content and acidity level were measured for each oil. A drying treatment process was performed if the oil did not fulfill the requirements in 
the ASTM D3487 [27] and ASTM D6871 [28] standards for the MI and NEI oils, respectively. Table 1 shows the initial properties of the oils prior to the accelerated thermal aging experiments.

Table 1. Initial properties of the MI oil, palm oil, and rapeseed oil

\begin{tabular}{cccc}
\hline \multirow{2}{*}{ Property } & \multirow{2}{*}{ MI oil } & \multicolumn{2}{c}{ NEI oil } \\
& & Palm oil & Rapeseed oil \\
\hline Moisture content $(\mathrm{ppm})$ & 29.5 & 108.1 & 165.5 \\
Acidity (mg KOH/g) & 0.0288 & 0.0525 & 0.0575 \\
DDP content & 19.592 & 11.174 & 35.021 \\
\hline
\end{tabular}

Five samples were prepared for each oil and laboratory accelerated thermal aging experiments were conducted based on the method proposed by Tenbohlen [29], as illustrated in Figure 1. The metal catalysts used to perform the accelerated aging were copper $(\mathrm{Cu})$, zinc $(\mathrm{Zn})$, aluminum $(\mathrm{Al})$, and iron $(\mathrm{Fe})$. The ratio of Kraft paper (KP) and pressboard (PB) to the oil by weight was 1:10 for each sample. The KP and PB were prepared according to the BS EN 60641 standard [30]. Next, the KP, PB, and metal catalysts were immersed in the oil for $24 \mathrm{~h}$ at room temperature $\left(25^{\circ} \mathrm{C} \pm 5^{\circ} \mathrm{C}\right)$ without air-conditioned. Then, the aging test was conducted by placing all of the samples in a vacuum oven. The oven was set at a temperature of $130^{\circ} \mathrm{C}$ for $100,250,500,1000$, and $1500 \mathrm{~h}$. For each aging period setting, the oil samples were taken out from the oven and left at room temperature for $24 \mathrm{~h}$ prior to measuring their properties. The moisture content, acidity, and DDP tests were conducted according to the ASTM D1533 [31], ASTM 664 [32], and ASTM D6802 [33] standards, respectively.

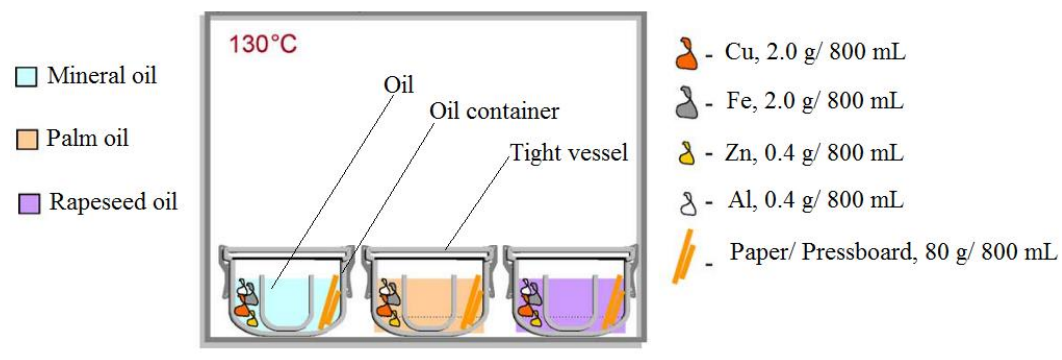

Figure 1. Accelerated thermal aging test setup [29]

\section{RESULTS AND DISCUSSION}

\subsection{Moisture content}

The electrical characteristics of an insulating liquid can be severely degraded by excessive moisture content. A high moisture content indicates that the insulating liquid is not suitable for some electrical applications due to degradation of its properties [31]. For this reason, moisture content measurements were performed on the oil samples using a coulometer (Model: 899, Metrohm AG, Switzerland).

Figure 2 shows the moisture content of aged MI and NEI oils investigated in this work. It can be observed that the NEI oils have significantly higher moisture content than the MI oil for different periods of aging. This is indeed expected because NEI oils have greater affinity towards moisture compared to MI oils [26, 34]. There are no obvious trends observed for the moisture content of NEI oils, as shown in Figure 2. The change in the moisture content of the MI oil is most significant after $250 \mathrm{~h}$ of aging, with a percentage difference of $59.52 \%$. Likewise, the change in the moisture content of the palm oil is highest after $250 \mathrm{~h}$ of aging, with a percentage difference of $142.73 \%$. The palm oil has the highest moisture content (289.1 ppm) after $500 \mathrm{~h}$ of aging. 


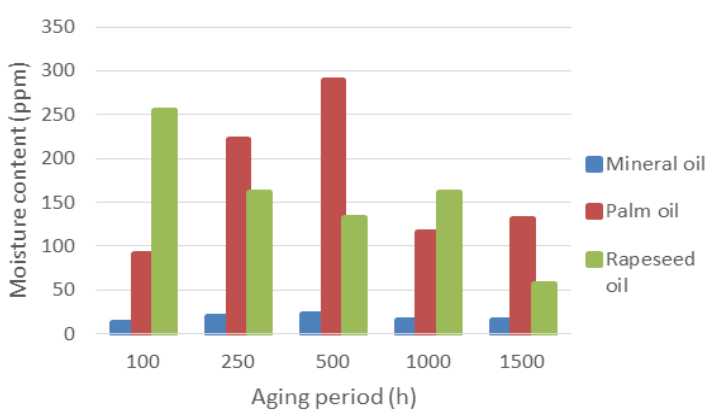

Figure 2. Moisture content of the MI, palm, and rapeseed oil samples for different periods of aging

\subsection{Acidity}

New and used insulating liquids may contain acidic constituents such as additives or degradation products formed in in-service transformers such as oxidation products [32]. Hence, acidity tests were performed to determine the acidity of the oil samples for different periods of aging using a compact titrator (Model: 848 Titrino Plus, Metrohm AG, Switzerland).

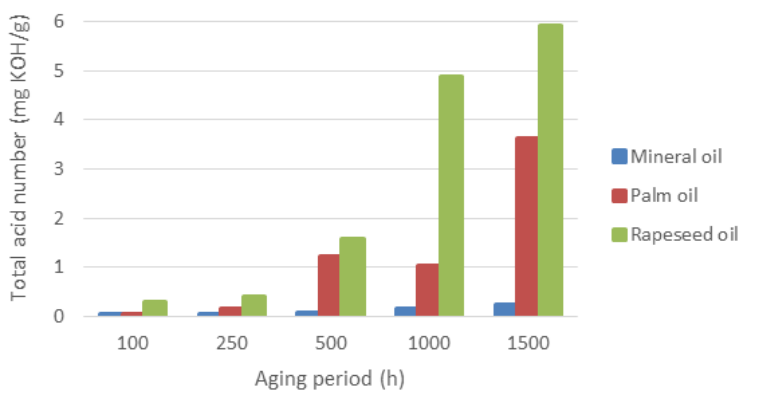

Figure 3. Acidity of the MI, palm, and rapeseed oil samples for different periods of aging

The acidity level is indicated by the total acid number (TAN), which is measured by the automatic potentiometer titration system. The TAN indicates the total amount of dissolved acids. Figure 3 shows the measured TAN values of the oil samples. In general, the acidity level increases after each oil undergoes the accelerated thermal aging process. The TAN of the MI oil, palm oil, and rapeseed oil increase by a factor of 9,69 , and 103, respectively, relative to their initial values after $1500 \mathrm{~h}$ of aging. The oxidation process and hydrolytic reactions with additional materials break down the fatty acid chains, which increases the TAN values of the oil samples.

\subsection{Relative content of dissolved decay products}

The relative content of DDP of the oil samples was determined using an ultraviolet-visible (UV-VIS) spectrophotometer (Model: UV-1800, Shimadzu Corporation, Japan). New oils are almost transparent to the monochromatic beam of light in the visible spectrum and the absorbance curve will shift towards longer wavelengths as the relative content of DDP increases. The DDPs in insulating oils are composed of various compounds such as peroxides, aldehydes, ketones, and organic acids. Each of these compounds are partially adsorbed on the large surface of the insulating paper, which leads to premature aging of power transformers. Hence, the presence of by-products in the insulating oil can be used as an indicator of the aging of the oil [33].

a. MI oil

Figure 4 shows the variation of the UV-VIS absorbance with wavelength for the MI oil samples aged under different periods of aging. It can be observed that the increase in absorbance is slow for the first $500 \mathrm{~h}$ of aging. The absorbance peak occurs at $391 \mathrm{~nm}$ after $1000 \mathrm{~h}$ of aging whereas the absorbance peak occurs at $435 \mathrm{~nm}$ after $1500 \mathrm{~h}$ of aging. It is evident that the absorbance decreases at a higher wavelength with an increase in the relative content of DDP of the MI oil. 


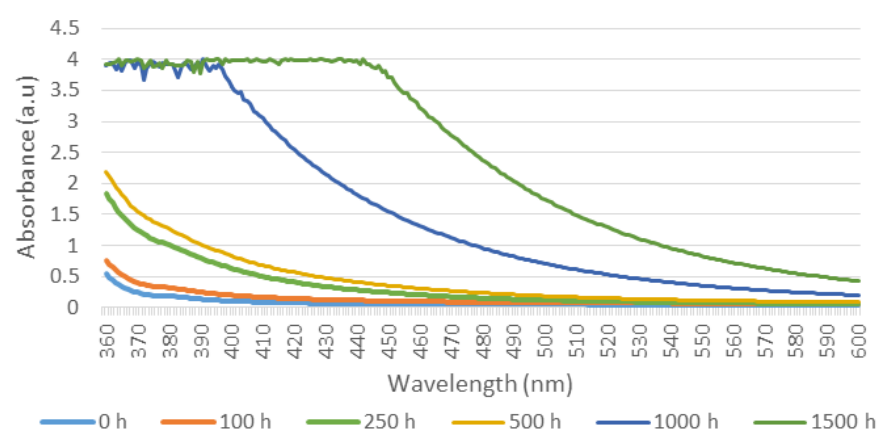

Figure 4. Variation of the UV-VIS absorbance with respect to wavelength for the MI oil

b. MI oil

The same trend can be observed for the palm oil, as shown in Figure 5. However, the increase in absorbance is slower for the first $500 \mathrm{~h}$ for the palm oil compared to that for MI oil. In addition, the absorbance peak occurs at a longer wavelength for the palm oil compared to that for the MI oil.

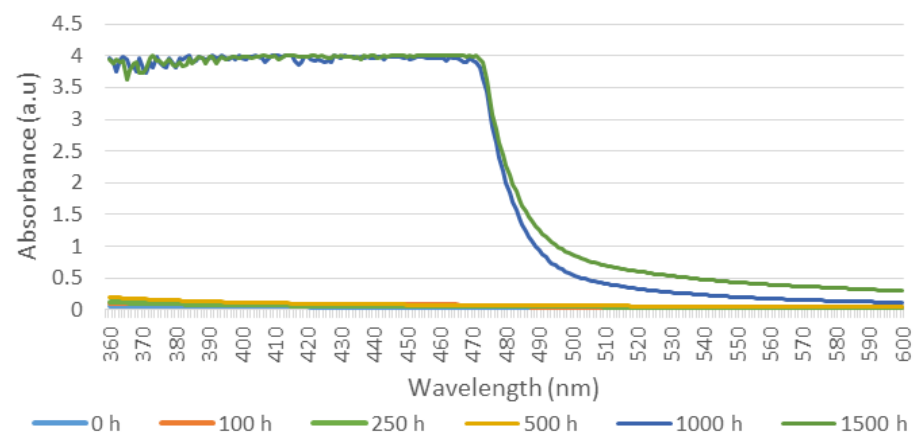

Figure 5. Variation of the UV-VIS absorbance with respect to wavelength for the palm oil

\section{c. Rapeseed oil}

In contrast, the rapeseed oil shows a different trend compared with the MI oil and palm oil, as shown in Figure 6. The increase in absorbance is quite fast for the rapeseed oil where the absorbance peak occurs just after $250 \mathrm{~h}$ of aging. The wavelength at which peak absorbance occurs increases with an increase in the aging period. It can also be observed that there is a shift in the wavelength at which the absorbance peak occurs from $430 \mathrm{~nm}$ (1000 h of aging) to $390 \mathrm{~nm}$ (1500 h of aging).

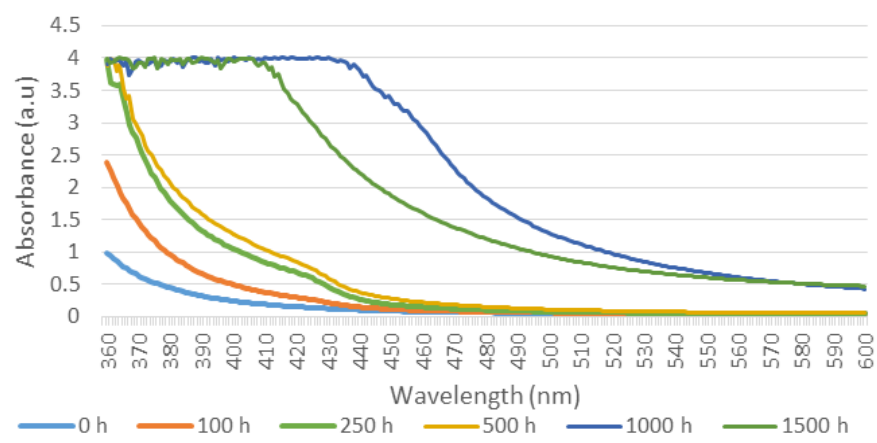

Figure 6. Variation of the UV-VIS absorbance with respect to wavelength for the rapeseed oil 
Figure 7 shows the relative content of DDPs for the MI, palm, and rapeseed oil samples determined from the area under the UV-VIS absorbance-wavelength curves shown in Figures 4-6. The initial relative content of DDP is 19.59 for the MI oil ( $0 \mathrm{~h}$ of aging) and the value increases significantly after $1000 \mathrm{~h}$ of aging (369.06). The relative content of DDP continuously increases to 580.73 after $1500 \mathrm{~h}$ of aging.

Even though the trends are similar for the MI and palm oils, the rate of increase in DDP is different between both oils. The palm oil has a higher rate of increase in DDP compared to the MI oil for the first 1000 $\mathrm{h}$ of aging. After $1000 \mathrm{~h}$ of aging, the rate of increase in DDP of the palm oil is lower than that of the MI oil, with a difference of $5.76 \%$.

A different trend is observed for the rapeseed oil, as shown in Figure 7. The relative content of DDP increases significantly for the first $1000 \mathrm{~h}$ of aging. However, the relative content of DDP then decreases from 535.07 to 436.51 after an additional $500 \mathrm{~h}$ of aging. This is due to the presence of sludge in the sample after $1500 \mathrm{~h}$ of aging, as shown in Figures 8(c) and 9. It is believed that the increase in acidity is the main factor that leads to the formation of sludge [35], which will reduce the dielectric strength of the oil. The presence of sludge can also reduce heat transfer if it is deposited on the insulating paper or inside radiator pipes [36].

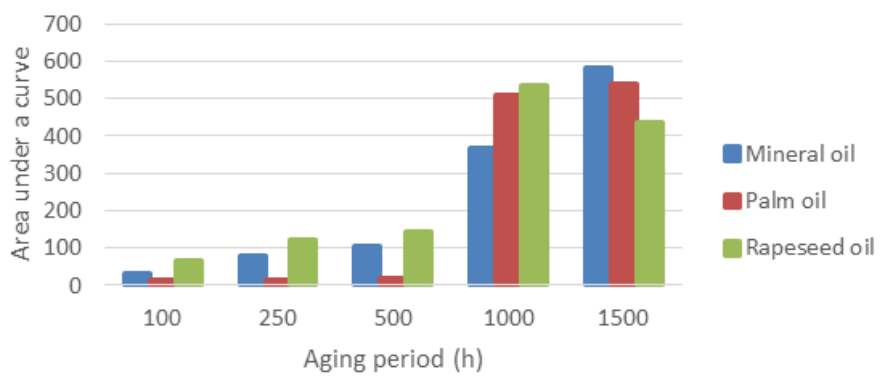

Figure 7. Relative content of DDPs of the MI, palm, and rapeseed oil samples determined from the area under the UV-VIS absorbance-wavelength curves within a wavelength of 360-600 nm

\subsection{Oil colour}

Oil colour is an important characteristic and it can indicate the degree of degradation of the oil. Figure 8 shows the photographs of the MI, palm, and rapeseed oil samples aged at $130^{\circ} \mathrm{C}$ for different periods of aging. It can be seen that the new oil samples are highly translucent. The colour of the oils becomes darker with an increase in the aging period and therefore, the oil colour change can be used as an indicator of the degradation rate of the oil due to aging. It is evident that the rate of discolouration is significantly higher for the MI oil compared with the NEI oils during the thermal aging process. Table 2 shows percentage increase in the properties of the MI, palm, and rapeseed oils subjected to accelerate thermal aging is compared.

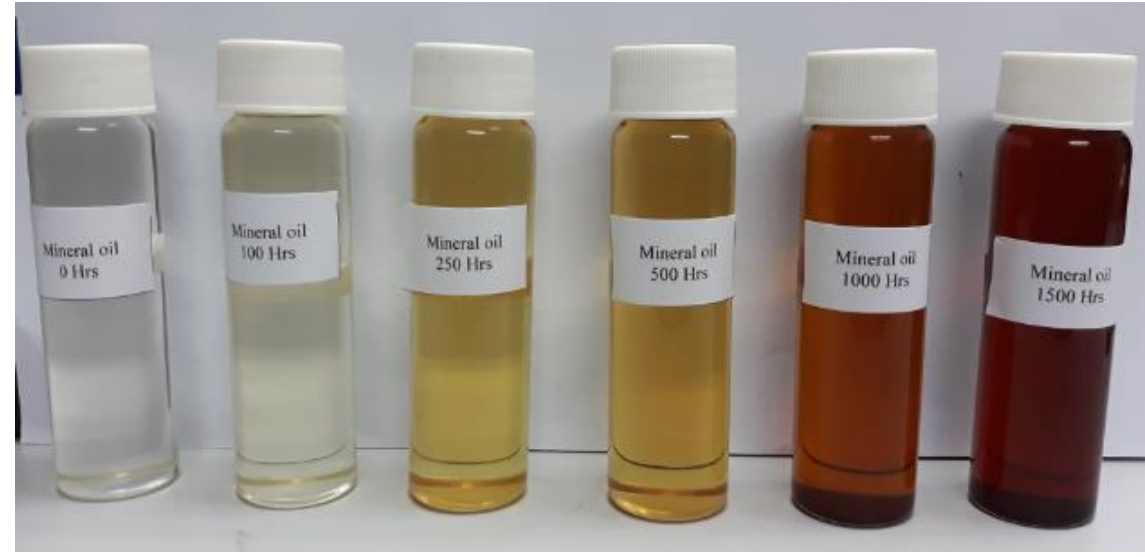

(a) 


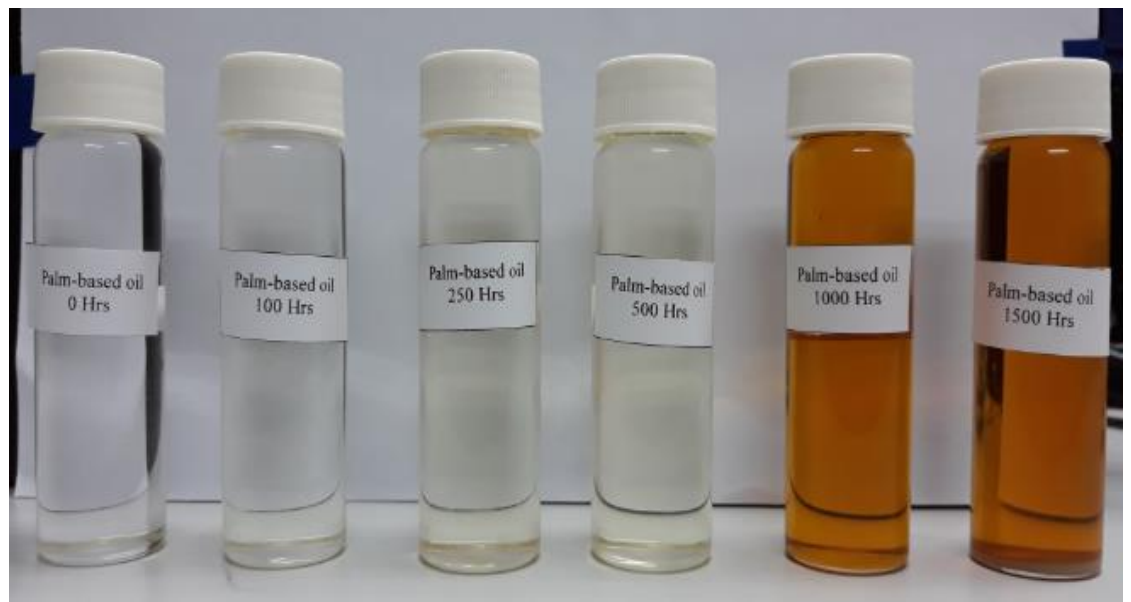

(b)

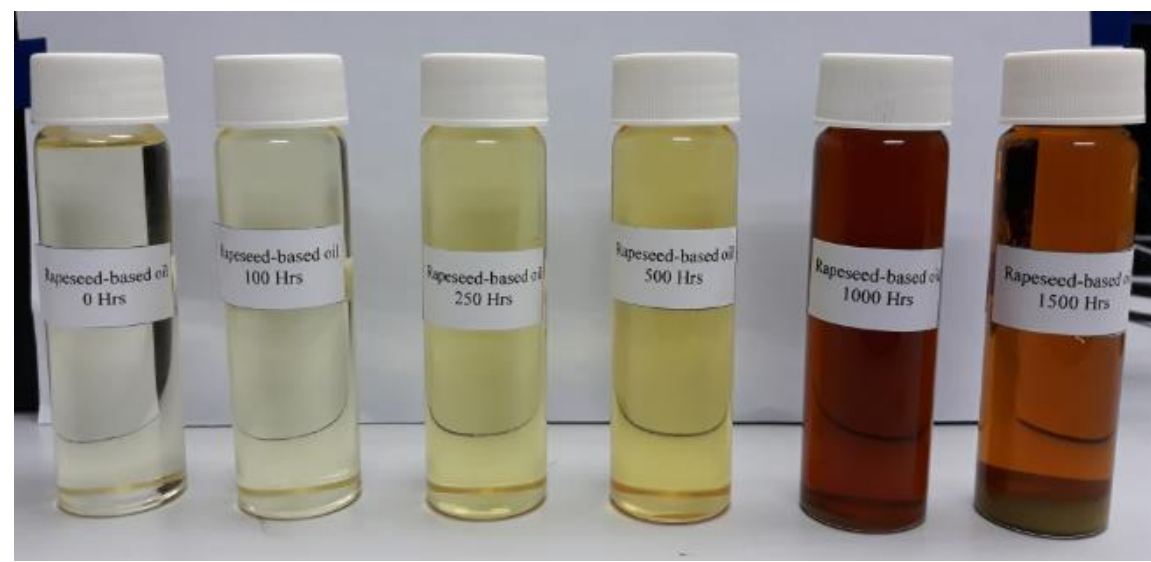

(c)

Figure 8. Colour of the, (a) MI oil, (b) palm oil, (c) rapeseed oil samples from $0 \mathrm{~h}$ to $1500 \mathrm{~h}$ of aging (from left to right)

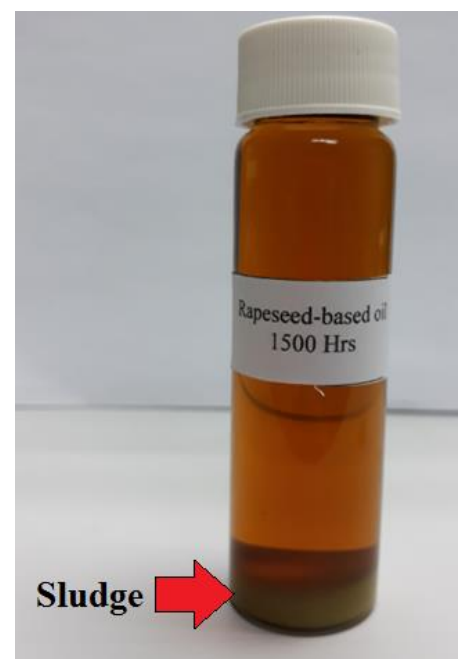

Figure 9. Formation of sludge in the rapeseed oil after $1500 \mathrm{~h}$ of aging 
Table 2. Percentage increase in the properties of the MI, palm, and rapeseed oil samples after aging relative to their initial values

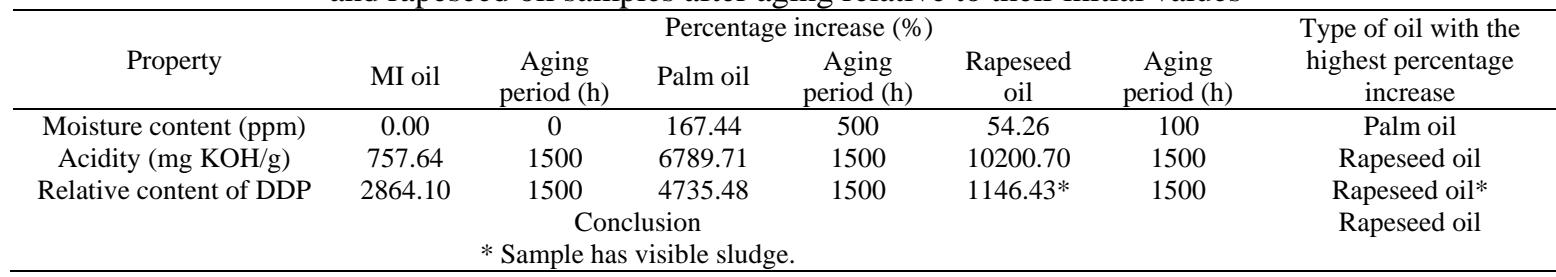

\section{CONCLUSION}

The percentage increase in the properties of the MI, palm, and rapeseed oils subjected to accelerate thermal aging is compared, as shown in Table 2. The percentage increase in the moisture content, acidity, and relative content of DDP of the oils after aging was determined relative to their initial values. The aging periods chosen for this comparison are the periods when the properties are maximum. In general, the oil with the highest percentage increase in moisture content, acidity, and relative content of DDP content is undesirable. Based on the results, the rapeseed oil is unfavorable compared to the palm oil because it has the highest percentage increase of acidity along with the presence of sludge after $1500 \mathrm{~h}$ of aging. The formation of sludge can hinder the circulation of the transformer oil, resulting in ineffective cooling.

\section{ACKNOWLEDGEMENTS}

The authors wish to acknowledge Universiti Teknikal Malaysia Melaka for funding this work under the following grant: FRGS/1/2016/TK04/FKE-CERIA/F00309 and FRGS/1/2017/TK04/FKE CERIA/F00332.

\section{REFERENCES}

[1] N. A. Bakar and A. Abu-Siada, "Fuzzy logic approach for transformer remnant life prediction and asset management decision," IEEE Trans. Dielectr. Electr. Insul., vol. 23, no. 5, pp. 3199-3208, Oct. 2016.

[2] T. K. Saha, "Review of Modern Diagnostic Techniques for Assessing Insulation Condition in Aged Transformers," IEEE Trans. Dielectr. Electr. Insul., vol. 10, no. 5, pp. 903-917, 2003.

[3] M. Ş. Vihacencu, A. Ciuriuc, and L. M. Dumitran, "Experimental study of electrical properties of mineral and vegetable transformer oils," UPB Sci. Bull. Ser. C Electr. Eng., vol. 75, no. 3, pp. 171-182, 2013.

[4] A. B. Norazhar, A. Abu-Siada, and S. Islam, "A review on chemical diagnosis techniques for transformer paper insulation degradation," in 2013 Australasian Universities Power Engineering Conference (AUPEC), 2013, no. October, pp. 1-6.

[5] LAI SIN PIN, "Furan Measurement in Transformer Oil By Uv-Vis Spectroscopy Using Fuzzy Logic Approach Lai Sin Pin," no. January, 2009.

[6] I. H. Zakaria, M. H. Ahmad, Y. Z. Arief, N. A. Awang, and N. A. Ahmad, "Characteristics of mineral oil-based nanofluids for power transformer application," Int. J. Electr. Comput. Eng., vol. 7, no. 3, pp. 1530-1537, 2017.

[7] S. S. A. Wahid et al., "Experimental investigation on vegetative oils under accelerated thermal ageing against their dielectric strength," Int. J. Electr. Comput. Eng., vol. 7, no. 3, pp. 1588-1593, 2017.

[8] S. A. Ghani, Z. A. Noorden, N. A. Muhamad, H. Zainuddin, M. I. H. C. Abdullah, and I. S. Chairul, "Dielectric strength improvement of natural ester insulation oil via mixed antioxidants: Taguchi approach," Int. J. Electr. Comput. Eng., vol. 7, no. 2, pp. 650-658, 2017.

[9] M. S. Mohamad, H. Zainuddin, S. A. Ghani, and I. S. Chairul, "Comparative study on the AC breakdown voltage of palm fatty acid ester insulation oils mixed with iron oxide nanoparticles," Int. J. Electr. Comput. Eng., vol. 6, no. 4, pp. 1481-1488, 2016.

[10] Ruijin Liao, Jian Hao, Lijun Yang, and S. Grzybowski, "Study on aging characteristics of mineral oil/natural ester mixtures-paper insulation," in 2011 IEEE International Conference on Dielectric Liquids, 2011, pp. 1-4.

[11] M. Rafiq et al., "Use of vegetable oils as transformer oils - a review," Renew. Sustain. Energy Rev., vol. 52, pp. 308-324, Dec. 2015.

[12] N. A. Othman, H. Zainuddin, A. Aman, S. A. Ghani, and I. S. Chairul, "The correlation between surface tracking and partial discharge characteristics on pressboard surface immersed in MIDEL en," Int. J. Electr. Comput. Eng., vol. 7, no. 2, pp. 631-640, 2017.

[13] U. M. Rao, Y. R. Sood, and R. K. Jarial, "Performance analysis of alternate liquid dielectrics for power transformers," IEEE Trans. Dielectr. Electr. Insul., vol. 23, no. 4, pp. 2475-2484, 2016.

[14] S. Ab Ghani, N. A. Muhamad, Z. A. Noorden, H. Zainuddin, N. Abu Bakar, and M. A. Talib, "Methods for improving the workability of natural ester insulating oils in power transformer applications: A review," Electr. Power Syst. Res., 2017. 
[15] C. Perrier and A. Beroual, "Experimental investigations on insulating liquids for power transformers: Mineral, ester, and silicone oils," IEEE Electr. Insul. Mag., vol. 25, no. 6, pp. 6-13, Nov. 2009.

[16] N. Azis, J. Jasni, M. Z. A. A. Kadir, and M. N. Mohtar, "Suitability of Palm Based Oil as Dielectric Insulating Fluid in Transformers," J. Electr. Eng. Technol., vol. 8, pp. 742-749, Mar. 2014.

[17] I. Fernández, A. Ortiz, F. Delgado, C. Renedo, and S. Pérez, "Comparative evaluation of alternative fluids for power transformers," Electr. Power Syst. Res., vol. 98, pp. 58-69, May 2013.

[18] S. Ab Ghani, N. A. Muhamad, Z. A. Noorden, H. Zainuddin, and M. A. Talib, "Oxidation stability enhancement of natural ester insulation oil: Optimizing the antioxidants mixtures by two-level factorial design," ARPN J. Eng. Appl. Sci., vol. 12, no. 6, pp. 1694-1700, 2017.

[19] S. Boudraa, L. Mokhnache, and I. Fofana, "A comparative study of impact of electrical stress and thermal aging on transformer oil," in 2014 IEEE 11th International Multi-Conference on Systems, Signals \& Devices (SSD14), 2014, pp. 1-6.

[20] I. Fofana, A. Bouaïcha, M. Farzaneh, J. Sabau, D. Bussières, and E. B. Robertson, "Decay products in the liquid insulation of power transformers," IET Electr. Power Appl., vol. 4, no. 3, p. 177, 2010.

[21] S. Karmakar, N. K. Roy, and P. Kumbhakar, "Effect of ageing in transformer oil using UV-visible spectrophotometeric technique," J. Opt., vol. 40, no. 2, pp. 33-38, Jun. 2011

[22] J. Wada, G. Ueta, S. Okabe, and T. Amimoto, "Method to evaluate the degradation condition of transformer insulating oil - experimental study on the hydrophilic and dissociative properties of degradation products," IEEE Trans. Dielectr. Electr. Insul., vol. 21, no. 2, pp. 873-881, Apr. 2014.

[23] K. Bandara, C. Ekanayake, and T. K. Saha, "Comparative study for understanding the behaviour of natural ester with mineral oil as a transformer insulating liquid," in 2014 IEEE Conference on Electrical Insulation and Dielectric Phenomena (CEIDP), 2014, pp. 792-795.

[24] J. Tokunaga, H. Koide, K. Mogami, and T. Hikosaka, "Comparative studies on the aging of thermally upgraded paper insulation in palm fatty acid ester, mineral oil, and natural ester," IEEE Trans. Dielectr. Electr. Insul., vol. 23, no. 1, pp. 258-265, Feb. 2016.

[25] T. K. Saha and P. Purkait, "Understanding the impacts of moisture and thermal ageing on transformer's insulation by dielectric response and molecular weight measurements," in IEEE Transactions on Dielectrics and Electrical Insulation, vol. 15, no. 2, pp. 568-582, April 2008.

[26] R. Liao, J. Hao, G. Chen, Z. Ma, and L. Yang, "A comparative study of physicochemical, dielectric and thermal properties of pressboard insulation impregnated with natural ester and mineral oil," IEEE Trans. Dielectr. Electr. Insul., vol. 18, no. 5, pp. 1626-1637, Oct. 2011.

[27] ASTM D3487, "Standard Specification for Mineral Insulating Oil Used in Electrical Apparatus 1," Significance, vol. 88, no. August 1988, pp. 1-7, 2001.

[28] ASTM D6871, "Standard Specification for Natural ( Vegetable Oil ) Ester Fluids Used in Electrical," 2015.

[29] S. Tenbohlen and M. Koch, "Aging performance and moisture solubility of vegetable oils for power transformers," IEEE Trans. Power Deliv., vol. 25, no. 2, pp. 825-830, Apr. 2010.

[30] BS EN 60641-2:2004, "Pressboard and presspaper for electrical purposes - Part 2: Methods of tests," 2004.

[31] ASTM D1533, "Standard Test Method for Water in Insulating Liquids by Coulometric Karl Fischer," pp. 1-5, 2015.

[32] ASTM D664, "Standard Test Method for Acid Number of Petroleum Products by Potentiometric," vol. i, pp. 1-10, 2011.

[33] ASTM D6802, "Test Method for Determination of the Relative Content Of Dissolved Decay Products in Mineral Insulating Oils by Spectrophotometry 1," vol. 02, no. Reapproved 2010, pp. 1-6, 2015.

[34] K. J. Rapp, C. P. McShane, and J. Luksich, "Interaction mechanisms of natural ester dielectric fluid and kraft paper," in IEEE International Conference on Dielectric Liquids, 2005. ICDL 2005., 2005, pp. 387-390.

[35] A. Bouaicha, I. Fofana, and M. Farzaneh, "Effect of oxygen on oil decay products formation," in 2009 IEEE Electrical Insulation Conference, 2009, no. June, pp. 133-137.

[36] N. Lelekakis, J. Wijaya, D. Martin, and D. Susa, "The effect of acid accumulation in power-transformer oil on the aging rate of paper insulation," IEEE Electr. Insul. Mag., vol. 30, no. 3, pp. 19-26, May 2014.

\section{BIOGRAPHIES OF AUTHORS}

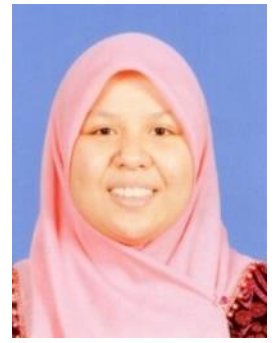

Nur Lidiya Muhammad Ridzuan. She received the BEng. (Hons) degree in Electrical Engineering from Universiti Teknikal Malaysia Melaka (UTeM) and currently doing the master's in Electrical Engineering also at UTeM. Her research interests are in electrical insulation, power equipments and insulation condition monitoring. 


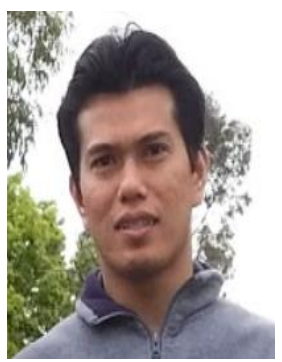

Norazhar Abu Bakar. He received the BEng. (Hons) in Electronics and Electrical from Leeds University, UK, MSc. (Eng.) in Control Systems from Sheffield University, UK and $\mathrm{PhD}$ in Electrical and Computer Engineering from Curtin University. Currently, he served as lecturer at University Teknikal Malaysia Melaka (UTeM), Malaysia. His research interests are in transformer condition monitoring and advanced control systems.

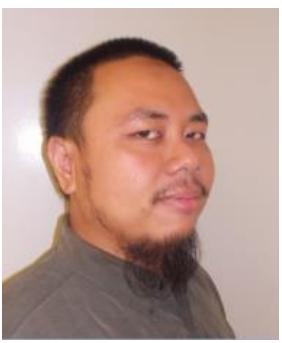

Sharin Ab Ghani. He received the BEng. (Hons) degree in Electrical Engineering from Universiti Teknikal Malaysia Melaka (UTeM) in 2008 and the MEng. Degree in Electrical Engineering from Universiti Tenaga Nasional, Malaysia in 2012. He served as a lecturer at Universiti Teknikal Malaysia Melaka (UTeM). Currently, he is a PhD student at Universiti Teknologi Malaysia. His research interests are in electrical insulation, power equipments \& insulation condition monitoring, and renewable energy.

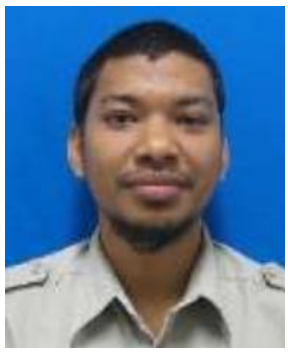

Imran Sutan Chairul He received the Bachelor of Electrical Engineering (Industrial Power) from Universiti Teknikal Malaysia Melaka (UTeM) in 2008. In 2012, he received the Master of Electrical Engineering from Universiti Tenaga Nasional. Currently, he is a lecturer at Universiti Teknikal Malaysia Melaka (UTeM). His research interests include liquid and gas insulation as well as condition monitoring of power transformer.

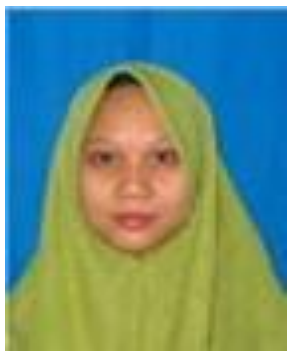

Nur Hakimah Ab Aziz. She received the BEng. (Hons) in Electrical Engineering from Universiti Teknologi Malaysia (UTM), MEng in Electrical Power Engineering from University of South Australia (UniSA), Australia and $\mathrm{PhD}$ in Electrical Engineering from University of Strathclyde Glasgow. Currently, she served as lecturer at University Teknikal Malaysia Melaka (UTeM), Malaysia. Her research interests include condition monitoring, diagnostics and prognostics and dielectric ageing. 